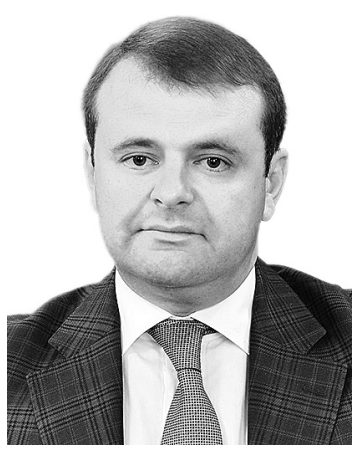

\title{
ЩОДО ПРАВОВОї ПРИРОДИ КЛОНУВАННЯ ЛЮДИНИ (МІЖНАРОДНІ ТА НАЦІОНАЛЬНІ ПОЗИЦії)
}

\author{
ТУРЯНСЬКИЙ Юрій Іванович - доктор економічних наук, член НКР \\ Конституційного суду України \\ DOI:10.32782/NP.2020.1.1 \\ https://orcid.org/0000-0002-4892-0653
}

Стаття акиентує увагу на правовій природі клонування людини. Сучасний розвиток науки, техніки, біомедицини та біології розширив можливості людини. Розвиток генетики призвів до можливості створення копї живого організму. В правовій думизі панує загальна думка - клонування юридично заборонена діяльність. Проте розвиток як медииини таке і правової ідеологї сучасної доктрини конституціоналізму ставить під сумність однозначність такого тлумачення.

Доведено, що правове регулювання залежить від виду клонування. Терапевтичне клонування передбачає створення відповідного середовища итучними методами для зародження та розвитку ембріону. Вони вирошуються з медичною изллю, а не для повноизінного розвитку. Репродуктивне клонування передбачає створення не тільки клітин, але всъого людсъкого організму.

Правова сфера невизначено регулюе відносини та можливості, що викликані таким розвитком. Загалом не існує однозначних міжнародних заборон до питання клонування. Ці заборони грунтуються на необхідності захисту ідентичності людини для збереження випадковості природного генетичного поєднання, що надає їй ӥ свободу та унікальність, а також запобігання ї̈ експлуатаий.

Більшість норм міжнародного характеру прийняті на початку тисячоліття, що вже саме по собі говорить про потребу оновлення та перегляду. Низка актів мають рекомендаиійний характер, або знайшла підтримку незначной кількості держав. Інституиійні органи на рівні
ООН, зокрема ЮНЕСКО також виявились скоріше площадкою для дискусї ніж органом, який може запропонувати консолідоване рішення.

На начіональному рівні окремих держав великі розбіжності в регуляторних підходах навіть у межах країн, шо проявляеться в повній забороні клонування, забороні тільки певного виду клонування, або взагалі відсутне правове регулювання иъого питання. Також констатовано багато з існуючих начіональних нормативних актів знаходяться в нестабільному стані, оскільки низка країн країни розглядають положення про перегляд.

Ключові слова: клонування, репродуктивне клонування, терапевтичне клонування, права людини.

\section{Постановка проблеми}

Швидкий прогрес в останні кілька десятиліть в галузі біотехнологій, що включають соматичні клітини та генну терапію, дає великий потенціал в регенеративній медицині та в лікуванні генетичних дефектів. Ці досягнення потребують розуміння наукових принципів, а також етичних та суспільних наслідків, перш ніж ці технології можуть бути застосовані клінічно. Однією 3 них 6 клонування. В правовій думці панує загальна думка - клонування юридично заборонена діяльність. Проте розвиток як медицини таке і правової ідеології сучасної доктрини конституціоналізму ставить під сумність однозначність такого тлумачення. Тому потребує додаткового аналізу сфера правового регулювання генної інженерії. 


\section{Теорія, історія держави і права, конституційне право}

\section{Стан дослідження}

Проблему правового регулювання прав людини, що повязані з розвитком медицини та біотехнологій піднімали багато науковців. Останнім часом сфера дослідження у відчизняній доктрині значно активізувалася, тому існують роботи як теоретичного, так $\mathrm{i}$ галузевого спрямування. Значну увагу присвятили такі науковці як С. Булеца, I. Жаровська, Ю.Бисага, С.Сливка, С.Стеценко, О. Скакун, В. Ковальчук та багато інших. Проте проблематика залишається новою, враховуючи широкомаштабність - малодослідженою.

Метою цієї наукової статті $є$ аналіз міжнародного та національного досвіду держав світу щодо правового регулювання питання клонування людини.

\section{Виклад основних положень}

Одним 3 головних первинних напрямків генної інженерії $\epsilon$ те, що генетична інформація організована у вигляді генів, утворених ДНК, які в деяких біотехнологіях можна маніпулювати для застосування в різних галузях науки. В даний час генна інженерія широко використовується в різних галузях медицини для отримання вакцин, моноклональних антитіл, тварин, які можуть бути використані в якості моделей захворювань або використовуватися як донори органів, генної терапії терапії, яка спрямована на відновлення правильної експресії генів у клітинах, що мають дефектну форму.

Геном вважається довгими ланцюгами нуклеїнової кислоти, що містить інформацію, необхідну для формування організму, що складається 3 малих субодиниць, які називаються нуклеїновими основами, які 6 спадковими. Таким чином, геном містить повний набір ознак, які є спадковими. Геном можна функціонально розділити на набори базових послідовностей, званих генами. Кожен ген відповідає за кодування білка, а альтернативні форми називаються алелями. Ген лінійної ланцюга має назву хромосоми, і кожен ген займає певне місце, місце. Тому сучасний погляд на генетику ге- нетики - це повний набір хромосом для кожної людини.

У сучасній молекулярній біології здатність маніпулювати молекулами ДНК називається клонуванням. Однак однієї копії рекомбінантної ДНК недостатньо. Реплікація одного організму зазвичай використовується для збільшення кількості копій [1]. Це дозволяє клонувати (створювати копії) живих істот.

Соматичний ядерний перенос (SCNT) був успішно використаний у 1997 році для створення клонованих овець Доллі. SCNT - це техніка, коли ядро донорської яйцеклітини (яйцеклітини) видаляється та викидається і замінюеться ядром із дорослої соматичної клітини (тобто клітин шкіри, жирових клітин і клітин печінки). Яйцеклітину стимулюють до поділу на бластоцисту (ранній ембріон 3 не більше ніж 100 клітинами), що має ідентичний генетичний склад 3 початковою донорською ядерною ДНК (клоном). Одним із притягань SCNT є те, що отримані плюрипотентні клітини матимуть такий же генетичний склад, як і пацієнт, оскільки пересаджене ядро несе ДНК пацієнта. SCNT не передбачає розмноження, оскільки сперма не використовується в техніці, а тому забезпечує альтернативний метод отримання стовбурових клітин для використання в терапії або в дослідженні.

Нині загальноприйнято виділяти дві можливості клонування людини, яке називають терапевтичне та репродуктивне. Перше передбачає створення відповідного середовища штучними методами для зародження та розвитку ембріону. Вони вирощуються 3 медичною ціллю, а не для повноцінного розвитку. 3 таких ембріонів виокремлюють стовбурові клітини. Їх цінність полягає в тому, що вони є підгрунтям для створення нових клітин, які необхідні людському організму. Ембріональні стовбурові клітини - це недиференційовані клітини ембріона i здатні породжувати всі тканини, що виявляються в організмі. При поділі вони мають властивість примножувати будь-які спеціалізовані типи клітин.

Репродуктивне клонування передбачає створення не тільки клітин, але всього людського організму. 
Правове регулювання клонування має міжнародне підгрунтя.

Активно питання пов'язане 3 клонуванням розпочалося 3 прийняттям Конвенції про захист прав і гідності людини щодо застосування біології та медицини (Конвенція про права людини та біомедицину) у 2017 р. У першу чергу це визначення загального принципу, який міститься в ст. 2 оскільки встановлено, що : «Інтереси та благополуччя окремої людини превалюють над виключними інтересами усього суспільства або науки». Також існує згадка про ембріони. «Якщо законодавство дозволяе проводити дослідження на ембріонах in vitro, воно забезпечує належний захист ембріона. Вирощування ембріонів людини для дослідних цілей забороняється» [2]

Загальна декларація про геном людини та права людини, яка прийнята у тому ж 1997 р. визначає особливу цінність геному людини, оскільки унормовано, що він «лежить в основі початкової спільності всіх представників людського роду, а також визнання їх до гідності і різноманітності. Геном людини знаменує собою надбання людства» (ст.1) [3]. Стаття 11 вперше вводить пряму заборону - «Не допускається практика, що суперечить людській гідності, така, як практика клонування в цілях відтворення людської особини». Однак акцент також проводиться на необхідності вжиття міжнародних заходів компетентними органами та державами, пропонується їм співпрацювати з метою виявлення такої практики і прийняття на національному та міжнародному рівнях для усунення гіпотетичного порушення законодавства.

Додатковий протокол до Конвенції про захист прав людини і гідності людської істоти в зв'язку з використанням досягнень біології та медицини, що стосується заборони клонування людських істот (ETS $\mathrm{N}$ 168) є першим і єдиним міжнародним правовим документом, розробленим у цій галузі. Реагуючи на успішне клонування ссавців, зокрема, шляхом розщеплення ембріона та перенесення ядер, Рада Европи хотіла запобігти подальшому дрейфу застосування цієї методики для людських можливостей.
Стаття 1 Протоколу забороняє «будьяке втручання, спрямоване на створення людини, генетично ідентичної іншій людині живою чи мертвою». Стаття 2 виключає звільнення від цієї заборони (наприклад, 3 міркувань безпеки населення, запобігання злочинності, охорони здоров'я населення або захисту прав і свобод інших осіб).

Ці заборони грунтуються на необхідності захисту ідентичності людини для збереження випадковості природного генетичного поєднання, що надає їй їі свободу та унікальність, а також запобігання ії експлуатації.

Обсяг Протоколу стосується виключно клонування людей. Тому не передбачається коментувати етичну прийнятність клонування клітин і тканин для дослідницьких цілей і для використання в медицині, сфера, в якій ці методи можуть виявитись цінними інструментами [4]. Звернемо увагу на його незначне поширення. Він був ратифікований лише 23 із 47 країн-членів Ради Европи.

У 2005 році на рівні Генеральної Асамблеі ООН розроблено «Декларацію Об'єднаних Націй про клонування людини» в п. b) вміщений заклик до держав-членів заборонити всі форми клонування людей в такій мірі, в якій вони несумісні 3 людською гідністю і захистом людського життя [5]. Декларація прийнята, але не одноголосно - 84 країни проголосували «за», 34 проголосували проти і 37 утрималися. Вчені вказують, що Декларація неоднозначно сформульована [6], тому отримала лише амбівалентну підтримку країн-членів ООН, тому цей документ вважається занадто слабким інструментом для того, щоб перешкоджати науково-дослідним заходам чи сприяти законним науковим починанням.

Враховуючи цей незадовільний результат, у 2008 році ЮНЕСКО (Організація Об'єднаних Націй $з$ питань освіти, науки та культури) створила Робочу групу з розгляду можливості юридично обов'язкової конвенції про заборону репродуктивного клонування людини. Робочу групу складали члени Міжнародного комітету з біоетики, створеного в 1993 році в рамках Програми ЮНЕСКО з біоетики. Він встановив, що недостатня ясність у міжнародному праві не 


\section{Теорія, історія держави і права, конституційне право}

допомагає цим державам ще формулювати національні норми чи політику щодо клонування людей.

Першим звітом Робочої групи був проміжний звіт, опублікований у вересні 2008 року. Він рекомендував нову, обов'язкову міжнародну конвенцію про заборону репродуктивного клонування людини[7]. Він піддався різким дебатам, тому Робоча група була більш обережною у своєму остаточному звіті від червня 2009 року. Вважаючи, що впровадження нового міжнародного нормативного інструменту буде передчасним, вона рекомендувала посилити глобальний діалог як альтернативу [8].

Після 4-х років роботи та обговорень, нездатність ЮНЕСКО досягти консенсусу щодо того, чи бажана є Конвенція про заборону репродуктивного клонування людини, означала, що рішення проти конвенції було прийняте за замовчуванням. У проекті підсумкової заяви Робочої групи 2011 року було зроблено висновок: «Чинні міжнародні нормативні акти не можна вважати достатніми для вирішення викликів сучасних наукових розробок та захисту інтересів країн, що розвиваються, які досі не мають певних регламентів у цій галузі.”[9] До цього часу ЮНЕСКО не просунулося жодного кроку розпочати розробку договору.

На регіональному рівні також наявні акти що стосуються клонування. П. г ст. 3 Хартії основних прав Европейського Союзу забороняє репродуктивне клонування людей, вважаючи його елементом права на недоторканість особи [10].

Тепер звернемся до національної правової політики держав світу, яка актуалізується у світлі «реконструкції міжнародного простору»[11, с.4]. Як зазначають багато коментаторів, існують великі розбіжності в регуляторних підходах навіть у межах країн, які вирішили створити відповідні закони та політику [12, с.301]. Жодна 3 країн не прийняла однакових регуляторних заходів щодо клонування, хоча ефект від тих, які були прийняті в деяких країнах, дуже схожий. $\mathrm{E}$ лише одна сфера регуляторної угоди - поки що жодна юрисдикція не прийняла законодавства, що дозволяє Репродуктивне клонування. Як наслідок, існують по суті лише два регуляторні підходи до нього: заборона або регулююча тиша. Законодавча тиша, як правило, означає, що такий вид клонування $\epsilon$ технічно законним у відповідній юрисдикції, хоча, якби це було зроблено, швидше за все, буде швидке реагування на регулювання.

Терапевтичне клонування $є$ джерелом значних змін у регуляторній діяльності. Незважаючи на те, що такий вид діяльності заборонений у сімнадцяти країнах, які вивчаються, він може бути дозволений у приблизно тринадцяти інших країнах. Аише Бельгія та Великобританія навмисно прийняли чи розширили законодавство з метою дозволу на створення клонованих ембріонів для дослідження. Орган з ліцензування Великобританії фактично ще у 2004 р. видав свою першу ліцензію на проведення такого виду клонування[13]. Аналогічно дозвільні підходи, хоча і незаконодавчі, були прийняті Китаєм (який у серпні 2003 р. Видав Міністерські положення, що дозволяють клонувати дослідження в терапевтичних цілях)] та Кореєю (де уряд ухвалює обмежені дослідження щодо обмежене соматичне дослідження ядерної передачі).

За висновком провідних дослідників у сфері медичного права Шон Д. Паттінсон та Тімоті Колфілд, такі країни як Фінляндія, Греція, Ізраїль, Росія та Швеція, «дозволяють терапевтичне лише тому, що їх законодавство має потенційні прогалини. Законодавство Греції є найяскравішим, так закон 3089/2002 прямо забороняє «репродукцію людини» будь-яким методом клонування, але терапевтичне клонування не згадується. Це, мабуть, було навмисним, оскільки положення, що дозволяє досліджувати ембріони дозволяє досліджувати «запліднені яйцеклітини», які є надлишковими після допоміжного репродуктивного лікування. Також, Пояснювальний меморандум законодавства проголошує - «заборонено лише репродуктивне клонування. Таким чином, можна вважати, що терапевтичне клонування дозволено ...»[14]. Науковці акцентують, що на наявності суперечки міжнародного та національного права, оскільки Греція, яка ратифікувала як Европейську конвенцію про права людини 
та біомедицину, так і їі Додатковий протокол про клонування.

Мало того, що між країнами існує велика розбіжність і велика невизначеність щодо обсягу діючих законів, багато з існуючих законів та політики знаходяться в нестабільному стані, оскільки низка країн країни розглядають положення про перегляд.

Приклад голландського законодавства, Закон про ембріони 2002 року. Цей Закон забороняє процедури, що проводяться з метою створення генетично однакових особин людини, і забороняє створювати ембріони для дослідження. I все-таки, с. 33 Закону дозволяє в майбутньому скасувати заборону на створення ембріонів для дослідження. Так само законодавство Канади говорить, що парламентський перегляд закону необхідний протягом трьох років після проголошення.

Деякі країни, такі як Ізраїль, Нова Зеландія навіть прийняли обмежене часом законодавство. Наприклад, ізраїльське законодавство зазначає, що протягом 5 років жодних втручань на клітини людини не буде здійснюватися з метою клонування людини або для створення людини за допомогою репродуктивних клітин, які зазнали постійної навмисної генетичної модифікації [15]. Крім того, Закон зазначає, що Міністр охорони здоров'я може (після задоволення ряду умов) дозволити створення людини за допомогою використання генетично модифікованих клітин.

\section{Висновок}

Сучасний розвиток науки, техніки, бедицини та біології розширив можливості людини. Розвиток генетики призвів до можливості створення копії живого організму. Правова сфера невизначено регулює відносини та можливості, що викликані таким розвитком. Загалом не існує чітких загальновизнаних міжнародних заборон загального характеру до питання клонування. Більшість норм міжнародного характеру прийняті на початку тисячоліття, що вже саме по собі говорить про потребу оновлення та перегляду. Низка актів мають рекомендаційний характер, або знайшла підтримку незначної кількості держав. Інституційні органи на рівні ООН, зокрема ЮНЕСКО також виявились скоріше площадкою для дискусії ніж органом, який може запропонувати консолідоване рішення.

На національному рівні окремих держав великі розбіжності в регуляторних підходах навіть у межах країн, що проявляється в повній забороні клонування, забороні тільки певного виду клонування, або взагалі відсутне правове регулювання цього питання. Також констатовано багато 3 існуючих національних нормативних актів знаходяться в нестабільному стані, оскільки низка країн країни розглядають положення про перегляд.

\section{Література}

1. Giassetti M. I., Maria F. S., Assumpção M. E. O. D. and Visintin J. A. Genetic Engineering and Cloning: Focus on Animal Biotechnology, Genetic Engineering. Idah Sithole-Niang, IntechOpen. May 22nd 2013. DOI: 10.5772/56071. URL: https://www.intechopen. $\mathrm{com} / \mathrm{books} /$ genetic-engineering/geneticengineering-and-cloning-focus-on-animalbiotechnology\#B66

2. Конвенція про захист прав і гідності людини щодо застосування біології та медицини: Конвенція про права людини та біомедицину від 04.04.1997 p. URL: http:// zakon3.rada.gov.ua/laws/show/994_334

3. Загальна декларація про геном людини та права людини від 11.11.1997 p. URL: http://zakon0.rada.gov.ua/laws/ show/995 575?lang $=$ uk

4. Додатковий протокол до Конвенції про захист прав людини і гідності людської істоти в зв'язку з використанням досягнень біології та медицини, що стосується заборони клонування людських істот від 12.01.1998 p. URL: http://zakon3.rada.gov.ua/ laws/show/994_526

5. Декларація Об’єднаних Націй про клонування людини від 08.03.2005 p. http:// zakon3.rada.gov.ua/laws/show/995_d57

6. Langlois, A. The global governance of human cloning: the case of UNESCO. Palgrave Commun 3, 17019 2017. URL: https://doi. org/10.1057/palcomms.2017.19

7. UNESCO. Report of the Working Group of IBC on Human Cloning and International 


\section{Теорія, історія держави і права, конституційне право}

Governance. 2008. Paris, France: SHS/EST/ CIB-15/08/CONF.502/2 (19 September 2008).

8. UNESCO. Report of IBC on Human Cloning and International Governance. 2009. Paris, France: SHS/EST/CIB-16/09/CONF. 503/2 Rev.2 (9 June 2009).

9. NESCO. Conclusions of the Seventh Session of IGBC. 2011. Paris, France: SHS/ EST/IGBC-7/11/CONF.202/4 (6 September 2011).

10. Хартія основних прав Європейського Союзу 07.12.2000 p. URL: http:// zakon3. rada.gov.ua/laws/show/994_524

11. Жаровська I.M. Державна влада: правові категорії: моногр. Аьвів: вид ЛКА, 2012.- 196 c.

12. Pattinson S. Reproductive cloning: can cloning harm the clone? Med Law Rev. 2002. V. 10. P. 295-307.

13. Human Fertilisation and Embryology Authority. HFEA grants the first therapeutic cloning licence for research Press release. 11 August 2004. URL: https://www.hfea.gov.uk/

14. Pattinson S. D and Caulfield T. Variations and voids: the regulation of human cloning around the world $B M C$ Med Ethics. 2004.V. 5: 9. doi: 10.1186/1472-6939-5-9

15. Prohibition of Genetic Intervention (Human Cloning and Genetic Manipulation of Reproductive Cells) Law, 5759-1999 URL: http://www.hinxtongroup. org/docs/Israel.html

\section{The legal nature of human cloning (international and national positions)}

The article focuses on the legal nature of human cloning. The modern development of science, technology, biomedicine and biology has expanded human capabilities. The development of genetics has led to the possibility of making a copy of a living organism. Legal opin- ion is dominated by the general opinion that cloning is a prohibited activity. However, the development of both medicine and the legal ideology of the modern doctrine of constitutionalism calls into question the unambiguousness of such an interpretation.

It is proved that legal regulation depends on the type of cloning. Therapeutic cloning involves the creation of a suitable environment by artificial methods for embryo birth and development. They are grown for medical purposes, not for full development. Reproductive cloning involves the creation of not only cells but of the entire human body.

The legal sphere is vaguely regulating the attitudes and opportunities created by such development. There are generally no clear international bans on the issue of cloning. These prohibitions are based on the need to protect human identity in order to preserve the chance of a natural genetic combination, which gives it its freedom and uniqueness, as well as to prevent its exploitation.

Most international norms have been adopted at the beginning of the millennium, which in itself speaks to the need for renewal and revision. A number of acts are either advisory or have been supported by a small number of states. Institutional bodies at the UN level, including UNESCO, have also proven to be more of a platform for discussion than a body that can propose a consolidated solution.

At the national level of individual states, there are great differences in regulatory approaches, even within countries, which is manifested in a complete ban on cloning, a ban on only a certain type of cloning, or no legal regulation at all. It's also stated that many existing national regulations are in an unstable state, as a number of countries consider revising some provisions.

Keywords: cloning, reproductive cloning, therapeutic cloning, human rights. 